\title{
Faroe Islands
}

National Cancer Institute

\section{Source}

National Cancer Institute. Faroe Islands. NCI Thesaurus. Code C16573.

An island group between the Norwegian Sea and the North Atlantic Ocean, about onehalf of the way from Iceland to Norway. 